


\title{
Cambiar la tabla de operación. El medium intermedial
}

\author{
Silvestra Mariniello
}

Este artículo gira en torno a la idea de que estamos experimentando una profunda crisis en nuestra (moderna) literacy y, sugiere, que la noción de intermedialidad podría ayudar a comprender la nueva literacy que se desarrolla al margen del logocentrismo. Contra toda una tradición filosófica que primero trata de comprender y nombrar a las sustancias, y luego, captar sus relaciones, la intermedialidad se enfoca en las relaciones y entiende las sustancias como puntos relacionales que demandan (y permiten) un profundo cambio en la manera como pensamos y operamos. Para estudiar tal crisis y los cambios involucrados, la autora cuestiona el paradigma intermedial como ha sido teorizado por el discurso académico contemporáneo; discute los conceptos de medium y mediación, corazón del concepto de intermedialidad, y trata de sugerir vías para la comprensión del contexto intermedial en el cual pensamos y actuamos.

Palabras Clave: imagen, intermedialidad, literacy.

This article revolves around the idea that we are experiencing a profound crisis in our (modern) literacy and suggests that the notion of intermediality might help understand the new literacy developing outside logocentrism. Against a whole philosophical tradition that tries first to understand and name substances and then to grasp their relations, intermediality focuses on relations and understands substances as knots of relations demanding (and allowing) a deep change in the way we think and operate. In order to study such a crisis and the changes involved, the author questions the intermedial paradigm as theorized by contemporary academic discourse; discusses the 
concepts of medium and mediation, which are at the core of the concept of intermediality, and tries to suggest ways of understanding the intermedial environment in which we think and act.

KEY WORDS: image, intermediality, literacy.

Fecha de recepción: 26 de marzo de 2010

Fecha de aceptación: 22 de julio de 2010 
Silvestra Mariniello

Universidad de Montreal

\section{Cambiar la tabla de operación. El medium intermedial}

Traducción de Esther Cohen

“¿Qué es la intermedialidad?”, se pregunta Eric Méchoulam en una entrevista para la revista Spirale, "¿un nombre arrojado sobre un conjunto vago de prácticas analíticas resultado de saberes ya desarrollados? ¿Un aparato teórico en vía de constituirse con su letanía de prácticas rituales y de cuestionarios estereotípicos? ¿Una apariencia engañosa? A mi modo de ver, todo lo anterior a la vez" "“Éclaircies à travers les brumes de l'intermédialité", 35). La intermedialidad, entonces, es un concepto polimorfo. Encontramos a menudo conceptos polimorfos y polisémicos en las ciencias humanas, pensemos en la "historia", pensemos también en la "cultura", para tomar los ejemplos más familiares. Se trata de conceptos ya institucionalizados (aunque se encuentren en perpetua transformación) y, por tanto, menos sospechosos que el reciente concepto de intermedialidad. ¿Cómo abordarlo? ¿Cómo visualizar los diferentes aspectos de su polimorfismo? ¿Qué nos revela?

En su dimensión más canónica la intermedialidad se refiere a las relaciones entre los medios masivos de comunicación. Para dar sólo algunos ejemplos, las relaciones entre la fotografía y la literatura en Fragments d'un crépuscule blessé de Célestin 
Monga o en Un acte de terreur de André Brink que Robert Fotsing analiza con tanta perspicacia en ese mismo volumen; entre la fotografía y la pintura en la obra de Edward Hopper; las relaciones entre el cine y la televisión en Hero de Stephen Frears o Mad City de Costa Gavras, o entre la música y la arquitectura en Son-O-House de Edwin Van der Heide y Lars Spuybroek, etcétera. A este nivel es ya necesario reconocer la importancia de lo que está en juego en la intermedialidad. Ésta reconoce en la técnica una dimensión central y revela su presencia ahí donde se había vuelto invisible (la escritura es una técnica, como el cine, a pesar de su transparencia); nos aparta del pensamiento de la representación y de la puesta a distancia para introducirnos más bien en el pensamiento de la mediación y de la inmanencia, como lo veremos mejor más adelante. La intermedialidad designa también el crisol de medios y tecnologías de donde emerge y se institucionaliza poco a poco un medio particular (Gaudeault, "Un média naît toujours deux fois"); da cuenta de la transferencia de materiales y técnicas de una cultura a otra; por ejemplo, el aparato cinematográfico, inventado en occidente, se asocia con el haikú o la pintura del vacío en Japón, o con el Verbo de la tradición oral en buena parte de los países africanos; el material "Aída”, conocido en el contexto del naciente nacionalismo italiano - donde Egipto no es más que una alegoría de la realidad italiana irrepresentable por razones políticas - , se adapta al contexto egipcio en la repetición cinematográfica del libreto: el material y la tecnología transferidos se transforman durante el proceso, ya que su identidad y su sentido son función de una relación con un contexto; ésta es la metamorfosis histórica que puede significar la intermedialidad. Pero ésta remite, sobre todo, a la evolución constante de los medios, de las comunidades y de sus relaciones, marca el pasaje de una teoría de la sociedad, que los medios contienen - concepción generalmente establecida en nuestros días - a una teoría o sociedad, socialidades y medios que se 
co-construyen y se destruyen permanentemente. Al hablar de cambios aportados por la imprenta a la sociedad europea de fin de siglo XV, Elizabeth L. Eisenstein muestra la extensión y la complejidad de la relación entre una tecnología y la sociedad que la produce, la utiliza y está atravesada por ella.

Una cosa es mostrar en qué han cambiado los métodos de producción del libro en el curso de la segunda mitad del siglo xv, o estimar los órdenes de grandeza de esta producción. Pero otra cosa es determinar cómo el acceso a una abundancia o una variedad acrecentada de documentos escritos ha afectado la manera de aprender, de pensar y de percibir las élites alfabetizadas. De manera paralela, una cosa es mostrar que la uniformización fue una consecuencia de la imprenta y, otra, determinar cómo las leyes, las lenguas o las estructuras mentales fueron afectadas por textos más uniformes (Eisenstein, La révolution de l'imprimé, 20).

En su obra la autora estudia las múltiples posibilidades de los “cómos" de la microhistoria de una época, dándonos un modelo que inspira a cualquiera que desee estudiar la co-construcción de sociedades, socialidades y tecnologías. Por otra parte, la posibilidad de comunicarse instantáneamente — vía el telégrafo, el teléfono y, más recientemente, el Internet - con cualquier habitante de otra parte del planeta o de ver/escuchar en directo desde nuestra casa, en una pantalla televisiva, en la computadora o en la radio, un acontecimiento que sucede en otra parte sabiendo que otros espectadores/auditores, en todo el mundo, lo ven con nosotros, ha cambiado profundamente la percepción y el pensamiento del espacio/tiempo y ha permitido relaciones entre los seres humanos impensables fuera de la sincronía, sea falsa o real. ${ }^{1}$ Las consecuencias son inmensas y tocan todos los

${ }^{1}$ Me refiero aquí a "Television, Set and Screen" en Mass mediauras, donde Samuel Weber deconstruye la sincronía de la imagen televisiva. 
aspectos del vivir-juntos así como la percepción que tenemos de nosotros mismos en tanto individuos.

Como lo afirman Deleuze y Guattari, un concepto es más bien "el contorno", "la configuración", "la constelación de un acontecimiento por venir". ${ }^{2}$ Nosotros ${ }^{3}$ hemos llegado a pensar la intermedialidad como el conjunto de condiciones que hacen posible los cruzamientos y la concurrencia de medios, el conjunto de figuras que los medios producen al cruzarse, la disposición potencial de los puntos de una figura en relación con los de otra. La intermedialidad es el conocimiento de sus condiciones, de la posibilidad de múltiples figuras, de la eventualidad con que los puntos de una figura remiten a los de otra. La intermedialidad es también, entonces, un nuevo paradigma que permite comprender las condiciones materiales y técnicas de transmisión y de archivo de la experiencia en el pasado como en el presente.

Contra toda una tradición de pensamiento que busca comprender a los sujetos o las sustancias después de captar sus conexiones o sus interferencias, el principio consiste aquí (al respecto de la intermedialidad) en ver actuar primero las relaciones y en concebir a los sujetos como los nudos (por definición provisionales) de conexión (Méchoulam, "Éclaircies", 34).

Siguiendo esta reflexión, que abre su entrevista, Eric Méchoulam dirá que más que inventar nuevos conceptos "se trata de cambiar de tabla de operación" (34). En este ensayo quiero abordar, pasando por tres etapas (sin orden cronológico), el cambio que implica la intermedialidad: una reflexión sobre el paradigma intermediático en relación con el lugar de su teorización, la uni-

${ }^{2}$ Discuto la definición de este concepto en la obra de Deleuze y Guattari, Qu'est-ce que la philosophie?, en mi artículo "Commencements" aparecido en el primer número de la revista Intermédialités.

${ }^{3}$ Le Centre de Recherche sur l'Intermédialité à l'Université de Montréal. 
versidad contemporánea; una breve discusión de los conceptos de medium y de mediación que se encuentran en el centro de la intermedialidad; y una definición del milieu intermedial.

\section{El paradigma intermedial}

En su importante estudio, "Remains to be seen. Intermediality, Ekphrasis, and Institution”, James Cisneros discute la intermedialidad inscribiéndola en el contexto de los cambios académicos que se han producido masivamente durante los últimos veinte años. La intermedialidad aparece como el síntoma del desmoronamiento de la universidad moderna, causada por la mundialización y la "comunicación virtual", y su explicación.

To consider the history and geography of the concept, then, we should revise it both as a symptom of changes in its institutional setting and as a tool created with the present socio-historical juncture in mind - one that can help to explain and to partially mold the shifting cultural field. If our initial question was whether intermediality is a symptom or an explanation for a historical juncture, and we are correct in saying that it is both, we now find ourselves before a second, more pressing question: how can we use intermediality to think and to explain a situation of which it is a symptom? And: how can intermediality explain itself as a symptom at the same time that it explains the situation of which it is a sign? (20).

Para responder a esta cuestión más urgente, el autor introduce la figura retórica de la ékphrasis, cuyo estudio le revela la diferencia, en tanto que factor constitutivo del tropo, y le ayuda a identificar el papel que la intermedialidad, sucesora de la ékphrasis, puede desempeñar en el interior de la institución académica. El poema que describe el objeto artístico y que incluso trata de adherirse a su forma está, no obstante, condenado 
a diferir de tal objeto en la materia y en el tiempo. El "anacronismo inherente" de la ékphrasis desempeña un papel importante en la argumentación de James Cisneros; es, en efecto, el concepto central que mantiene unidas la retórica, las ruinas de la universidad (y de la cultura) moderna(s) y la intermedialidad. La ékphrasis es "una marca de exterioridad y de anterioridad que el objeto descrito transfiere a las imágenes verbales" (22). ${ }^{4}$ Lo que la figura constituye reside precisamente en sus limitaciones en tanto que construcción verbal, la identidad imposible con el objeto hacia el que tiende y por el cual resulta afectado. Pasando por una discusión de Laocoön de Lessing y de la lectura que W. Thomas Mitchell hace, James Cisneros muestra que la ékphrasis opera contra la corriente de un saber organizado por disciplinas de las que Lessing puede considerarse como el fundador.

Lessing's firm rejection of ekphrasis should be understood within his parallel preoccupation with national character and each art's intrinsic nature, where artistic hybridity would be correlative to the blurring of national identity [...] The priority Lessing gives to the integrity of community in his treatise on artistic limits thus anticipates in important ways the modern university: a secular national space within which artifacts are produced and evaluated, and where cultural production takes on meaning according to a hierarchy of arts or disciplines [...] Now this disciplinary complex is changing, which partly explains the renewed attention turned to the figure of ekphrasis that Lessing rejects (23-24).

La fuerza perturbadora de la ékphrasis está en su temporalidad, que elude las divisiones que Lessing quería imponer. Como lo muestra la lectura que James Cisneros hace de la Ode on a Grecian Urn (1819) de John Keats, épocas diferentes se superponen

4 "Remains to be seen. Intermediality, Ékphrasis and Institution": "a mark of exteriority and temporal precedence that the object described transfers to the verbal images". 
en un movimiento que huye del progreso y de la linealidad, y cuestiona la posición del sujeto que en lo sucesivo duda de ella misma.

The ode first shows us the ruins of another era, a cultural artifact that will remain after the inexorable advance of time. It then considers the urn as a historical agent that can be made to speak - a mute witness around which historical discourse gravitates, a historical remain that engenders stories. And finally, its ekphrasis culminates when the urn speaks and when the vessel, now ravished, unveils the secret that was still borne in its quitness: it climaxes when we penetrate the urn's virginal outer casing and de-crypt its inner burial contents, making legible or visible the remains within (26).

Otro sujeto, el sujeto humano, pero que comparte con él la capacidad de hablar y de engendrar historias, aparece y desafía el saber del narrador y del lector, su sentido del tiempo. La verdad emerge de la coexistencia de temporalidades diferentes como de la coexistencia del mito y la historia que impregna la vida cotidiana. Como la ékphrasis, la intermedialidad habita una temporalidad compleja donde muchos medios están copresentes de manera anacrónica y el sujeto ya no es soberano, la intermedialidad se convierte, entre otras, en el lugar a partir del cual se miran las ruinas del universo moderno.

Whose historic role has been to institute subjects for the nationstate through a cultural pedagogy, crystallizing in the notion of Bildung that links personal development to subjective formation (28).

Esta "fabricación" de sujetos por/en el Estado-nación implicaban el establecimiento de toda suerte de compartimientos y de oposiciones: entre las disciplinas, las artes y los campos del saber, entre el sujeto y sus objetos de conocimiento, entre el pensamiento y los afectos, lo ideal y lo material, lo racional y lo irracional. Implicaba también la instrumentalidad de la técni- 
ca, su transparencia y su exterioridad frente al pensamiento y la creación. La intermedialidad que se desarrolla en la resistencia a esos compartimientos y oposiciones nos hacía conscientes de las ruinas de ese sistema de valores y nos permitía penetrarlos y hacerlos hablar. ¿Para dirigirnos a qué futuro? James Cisneros parece más bien escéptico. La imagen de la intermedialidad como síntoma de "la universidad en ruinas" y emblema de su heredero, la universidad-empresa, es al menos tan fuerte en su discurso como aquel que la resistencia lleva a cabo por ese concepto polimorfo y sus prácticas. Nuestra responsabilidad es, podríamos decir con Derrida, hacer de la universidad "un último lugar de resistencia crítica — y más que crítica - frente a todos los poderes de apropiación dogmáticos e injustos" (Derrida, L'Université sans condition, 14).

\section{Real-Imaginario}

La intermedialidad presupone, como lo hemos visto parcialmente y como lo desarrollaremos más adelante, una crítica de la representación, concepto y práctica sobre las que se sostiene la modernidad: ${ }^{6}$ la representación implica la transparencia de la técnica y de la tecnología, mientras que la intermedialidad insiste en la visibilidad de la técnica sobre su opacidad y llama la atención sobre la mediación, la materia y la diferencia. En un ensayo muy importante, aparecido como work in progress en la colección dirigida por Jenaro Talens, "Eutopías", y retomado más tarde parcialmente en The Culture of Literacy, ${ }^{7}$ Wlad Godzich identifica la crisis de la literacy moderna, de la cual la intermedialidad es a

${ }^{5}$ Cfr. Bill Readings, The University in Ruins.

${ }^{6}$ Empleo aquí "representación" en el sentido de "concepción de mundo", elaborado por Martin Heidegger en el ensayo "La época de la imagen del mundo".

${ }^{7}$ Cfr. las obras de Wlad Godzich, The Language Market under the Hegemony of the Image y The Culture of Literacy. 
la vez un síntoma y una explicación, como uno de los problemas esenciales de nuestro tiempo. Detengámonos en algunos puntos centrales de su texto para comprender mejor las posturas políticas y filosóficas de la intermedialidad.

En The Language Market under the Hegemony of the Image, leemos que la representación es una característica distintiva de la modernidad y, de manera más precisa, que "modernity operates by means of images of the world", como Heidegger lo mostró en su "Die Zeit des Weltbildes" (Godzich, The Language Market, 10). Foucault, cuya obra es, de acuerdo con Godzich, un comentario y una corroboración de la tesis que Heidegger presenta en este ensayo, define las concepciones del mundo como discursivas por naturaleza: "worldviews are discursive constructs of which the archeology could be undertaken" (10). Eso significa que puede haber tantas concepciones de mundo (y de mundos) como de discursos. Encontramos aquí la noción de posibilidad, una noción crucial para la modernidad, pero que tuvo igualmente, como lo admite Kant, un papel devastador (10). Si todas las concepciones del mundo son posibles, ya no podría haber "grandes relatos"8 que estuvieran a cargo de la verdad (en historia, política, ciencia, religión, etc.). Las representaciones discursivas del mundo presuponen una concepción del lenguaje en tanto construcción, separada de la existente. El sujeto moderno debe recordar que hablar es someterse a las reglas del lenguaje, es construir, falsificar, ficcionalizar, por una parte y, por la otra, decir la verdad estableciendo el mundo como referente, y la capacidad del lenguaje de remitir al mundo.

The modern subject must simultaneously bear in mind that to speak is to submit to the rules of language, to construct, to falsify, to fictionalize on the one hand, and to tell the truth by

${ }^{8}$ Cfr. La condition postmoderne de Jean-François Lyotard. 
establishing the referentiality of the world, of the worldview on the other (11).

Esta alternancia entre el olvido y el recuerdo (olvidar que el lenguaje es una construcción y que, en consecuencia, implica la ficción y ya no puede decir la verdad del mundo) impregna tres momentos diferentes de la modernidad (12): el momento en el que el sujeto se da cuenta que la verdad en la que creía no era más que una construcción; el momento en que esta mentira es recuperada en cuanto verdad subjetiva: el sujeto no pretende decir la verdad, pero afirma que lo que dice es lo que cree verdadero; $y$, en fin,

the third moment in which the modern subject shies away from the violence presupposed by the regime of belief, and sheds belief itself. The abandonment of belief marks the advent of cynicism, and the subject accepts the effect of falsehood and decides to no longer stand by the possibility of thinking that a unique view of the world is necessary [...] we enter the epoch of modern imaginary in which arbitrariness reigns and the symbolic (as the instance of Law) is neutralized. What does this entail? Modern consciousness knows itself to be a consciousness of falsehood and accepts this fact; it knows that this means that it cannot generate a narrative capable of totalizing the meaning of existence and of the world. This ultimate step in the demystification of the world, accelerated by some historical catastrophes (Auschwitz, Hiroshima, the Gulag, [...]), leads the subject to give up truth (the Law) altogether and to accept the advent of the imaginary by instituting fiction as the way to constitute subjects and the world (14-15. Las cursivas son mías).

Este pasaje es uno de los más intrigantes del ensayo y la discusión del acontecimiento de lo imaginario es justamente lo que permitirá definir mejor el contexto y lo que está en juego en la intermedialidad. El acontecimiento de lo imaginario, que se produce a partir de una cierta comprensión del lenguaje en tan- 
to institución que se encuentra "en el origen de todas las instituciones" (16), coincide paradójicamente con un fuerte debilitarse del lenguaje cuyo funcionamiento está embrollado por las imágenes que, como nos recuerda Wlad Godzich, están en su casa en el imaginario. Este tercer momento que instituye la ficción como la manera de constituir a los sujetos y al mundo, es contemporáneo de la propagación de las imágenes y de los sonidos reproducidos mecánicamente por la fotografía, la radio, el cine, el gramófono, etc. Para ilustrar la competencia entre la imagen y el logos, Wlad Godzich examina el caso de la fotografía: "If language proposes us a discourse on the world, photography is a discourse of the world" (17).

By giving us things the way they are, photography confers upon them an imaginary presence that no mode of representation had achieved until then. Originally, image means imitation: the image that imitates the world remains distinct from the world. We now have images that coincide so much with the given that they abolish themselves as images in order to become the given magically repeated (cf. Walter Benjamin). In the plastic image of painting, the world was being negated, whereas now we have a world affirmed in itself. Images now allow for the paradox that the world states itself before human language (18).

Este pasaje y la reflexión que se deduce de él hacen explícito lo que se sub-entiende (sin que lo reconozcamos) en todos los estudios sobre el cine y la fotografía en tanto que re-producción de la realidad: dirige de nuevo la atención de la relación entre la imagen y lo real a la naturaleza imaginaria de lo que está dado como real. Más que decir que algo es imaginario, pero parece real, y cuestionar la forma en que esta impresión de realidad se produce (afirmando la primacía de la realidad), Wlad Godzich dice: la imagen confiere una presencia imaginaria a lo real, el mundo existe en cuanto imagen y la imagen se adhiere a la realidad del mundo que está presente en ella fuera de la oposi- 
ción real/imaginario. La frase "es imaginario, pero parece real" se convierte en "es real $y$ es imaginario". El mundo, "mágicamente repetido" a través de la reproducción mecanizada, está presente en la imagen que ya no es una representación (que ya no es discursiva) y adquiere, a su vez, la calidad de imagen. Al borrar la distancia entre la imagen y su referente, la fotografía y la televisión no crean un imaginario a partir de la realidad que reproducen, la hacen presente en tanto que imagen. El análisis de Wlad Godzich resuena en el artículo de James Cisneros, "Imaginary of the End, End of the Imaginary. Bazin and Malraux on the Limits of Painting and Photography", que introduce en la discusión la noción de diferencia, crucial en esta ecuación aparente entre el modelo y la imagen.

[...] the image is the model. The hinge lies between the two natures, the copula shown by the enunciative force that places us at the limits of being, a differential fold between identical figures (Cisneros, "Imaginary of the End", 159).

En el paradigma baziniano, dice James Cisneros, la repetición de lo que está dado (del mundo) "muestra los límites enunciadores de un momento" (159), cuando el sujeto muestra por derecho alguna cosa que es a la vez idéntica y diferente de su materialización en la foto. El texto de James Cisneros se entrega indirectamente a un diálogo que inspira, junto con el de Wlad Godzich, y aporta elementos importantes al debate sobre la fotografía en el contexto del fin de la literatura moderna. Su estudio se desarrolla a partir de un análisis original y perspicaz del célebre texto de Bazin, L'ontologie de l'image photographique que lee centrándose en la noción de agency y de manera más precisa, alrededor del sujeto en relación con el medium. Si una de las características de la modernidad era la constitución del sujeto en relación con el logos, aquí se trata de la constitución del sujeto en relación con el medium fotográfico, en relación con 
el "framing", como lo especifica James Cisneros. La gran intuición de Bazin fue la del carácter deíctico de la fotografía, "the movement between the image's framing and the subject that is constituted" (156).

Unlike painting, a spiritual form of inner expression, photography indicates the series of exterior relations that constitute the gaze as a locus of enunciation. Its enunciative force repeats that gesture of an infant who without speaking points beyond the frame, who shows deictically what cannot be said according to the specific discursive parameters of the plastic image. The deictic ambivalence doubles the world, pointing to the border between the intelligible and the mysterious (152-153. Cursivas mías).

Esta lectura del ensayo arroja una nueva luz sobre la función epistemológica de la fotografía y de todos los medios que se basan en ella.

Where the framing shows the potential of an image-language, the content of the photo, its composition of line, light and color, gives sense to that potential after its communion with a viewing subject. Bazin's ontology is the framing — not the frame, but the act situating it - that makes an image and the viewer correlative terms in a matrix where a visual language takes place (154).

Hay una diferencia entre la presencia indexical de la fotografía y el contenido de la foto que el lenguaje puede tratar. La deixis, constitutiva del acto de tomar una foto, escapa al lenguaje o, más bien, identifica sus límites así como los límites de un sujeto que trata de captar el mundo y que se desbarata en el proceso. ${ }^{9} \mathrm{El}$ acontecimiento de lo imaginario es a la vez el reconocimiento

${ }^{9}$ En mi estudio sobre Koulechov, he discutido brevemente la propuesta de cine-ojo en Vertov. Vertov hace decir a la cámara: "Yo soy el cine-ojo. 
del lenguaje en tanto que construcción que nos da al sujeto y al mundo y hace del artificio la nueva ley, y el estallido de la competencia conflictual entre el lenguaje y las imágenes que conduce a lo que Wlad Godzich llama un mundo sin nosotros, en el cual una realidad no mediatizada por el logos se convierte en expresión misma del imaginario y lo sustituye, o a lo que James Cisneros llama "World without exterior" en el que "el mapa que cubre al mundo no lo remplaza pero, de manera similar a la fotografía, se adjunta a la naturaleza como otro componente de su nuevo orden" (Cisneros, "Imaginary of the End", 167). Las imágenes analógicas y numéricas nos dan "un mundo que ha sido sometido al trabajo del lenguaje y que ha salido de él intacto" (Godzich, The Language Market, 20); esta poderosa y sugerente frase evoca la crisis de la literacy moderna y desafía

Yo soy un constructor. Yo te he situado a ti, creado hoy por mí, en una cámara estupenda que no existía hasta este momento, también ella creada por mí. En esta cámara hay doce muros reunidos por mí en diversas partes del mundo" (Michelson, Kino-Eye. The Writings of Dziga Vertov, 17). ¿Es posible interpretar este párrafo de Vertov como si la cámara tomavistas sustituyese al sujeto humano reivindicando sus atributos? Vertov da la palabra a la cámara tomavistas, la hace hablar atribuyéndose el pronombre sujeto yo, la provee de voluntad; en verdad, pero, al mismo tiempo, da a este yo unos caracteres que no son los de un sujeto psicológico. En el momento en que el cine-ojo se constituye como persona, niega los atributos de los que la tradición del pensamiento occidental ha provisto al sujeto-persona, por una pluralidad que no sólo no le pertenece, sino que amenaza su existencia y estabilidad. Pluralidad en la mirada, en la posición, en la naturaleza (el cineojo es al mismo tiempo el instrumento mecánico y la escritura). Por tanto, a través de la personificación el concepto mismo de sujeto paradójicamente se niega. — ¿Cuál es el status del cine-ojo? — me preguntaba. La cámara de Vertov no es ni un instrumento mecánico, ni figuradamente, una persona (un sujeto más potente, por ejemplo), ésta es el medium a través del cual se hace posible la acción. El cine-ojo es al mismo tiempo la cámara tomavistas y el montaje, no es posible reconducirlo a un referente, ya sea éste un objeto mecánico, o una serie de reglas gramaticales (de montaje). Para esta discusión cfr. Silvestra Mariniello, El Film: el Fin del Arte, 60-61. 
a los investigadores a trabajar en esta dirección. Lo que está en juego aquí no es la oposición binaria entre la época de la literacy y la época del audiovisual, sino el reconocimiento de la insuficiencia de la literacy moderna (textual) frente a las diferentes prácticas sociales de la visualidad humana que han sido domesticadas, ignoradas o hechas de lado en la cultura de la literacy y que se imponen a través de los intercambios cada vez más frecuentes e intensos y el rápido desarrollo de los medios audiovisuales, especialmente el cine y la televisión. El concepto de intermedialidad parece poder suministrar señales en el camino de la renovación de la literacy, con el intento de llenar las distancias entre nuestra experiencia y nuestra comprensión de esta misma experiencia. La intermedialidad lleva el análisis fuera del campo lingüístico y literario (intermedialidad y no intertextualidad, por ejemplo) e invita a pensar la mediación, la tecnología, la materia. Si la realidad no está mediatizada por el logos, si el logos no es más el mediador universal del Estado moderno que ha sido desde el inicio, ¿acaso la realidad es inmediata? Para afirmar la debilidad del lenguaje frente a la velocidad de las imágenes y de los sonidos, Wlad Godzich no duda en tomar posiciones extremas, casi paradójicas. La importancia de este ensayo no debería ser subestimada: trata de la distancia dramática entre la experiencia vivida (nuestra vida con los medios) y un discurso que aún pertenece a la literacy moderna (textual o escrita) y que trata de explicar, describir, transmitir y comprender tal experiencia pero que es a menudo inadecuada para esa tarea. Actualmente tenemos la impresión de vivir en una transición: resentimos el cambio pero al mismo tiempo hacemos la experiencia de la falta de "medios" para nombrar o conocer lo nuevo o nuestra relación con esto nuevo.

The mystical quality of the photographic image stems from the indication of its limits for human understanding, which may decipher its expression but which cannot objectively grasp its enunciation (Cisneros, "Imaginary of the End", 156). 
Más que "its limits for human understanding", podríamos decir aquí con Wlad Godzich, "for modern literacy", que está basada en la distancia (entre el sujeto y el mundo) y la oposición (al interior de un sistema binario de valores), así como sobre la atribución de la acción (agency) a un sujeto originario capaz de manipular la tecnología para decir, conocer, imitar y controlar el mundo. La fotografía y el cine manifiestan otra presencia en que la noción de una agency que manipula un medium instrumental no puede dar cuenta; esta otra presencia exige, para ser comprendi$\mathrm{da}$, que uno salga del lenguaje en tanto mediador universal, y que uno permita que el lenguaje sea invadido por las imágenes, que el discurso sea transformado por lo que le opone una resistencia; por lo que exige que reconozcamos la presencia de lo figural en el lenguaje cuando la configuración del saber basado en la lógica (Man, "The Resistance to Theory", 13-14) —en tanto que puente entre el lenguaje y el mundo- se transforma en otra configuración.

In a history of the media, photography's violent clash with the history of the images that precede it also signals its value as the end of an imaginary. The rupture with painting becomes clear if we follow Bazin's claim that the essence of photography is the agential independence of the technology that produces its images. It also makes clear the institutional controls deployed to suture the break, the ideological apparatuses that subdue the technology's uncanny doubling with narratives of permanence and continuity where the medium is an instrument in the hands of an able identity. The established discursive economy reacts against this emergent imaginary, institutionalizing the new image to shelter the subject from the technological medium's heterogeneous constructive agency (Cisneros, "Imaginary of the End", 159-160).

La intermedialidad que, como dice James Cisneros, nos hace tener acceso a los restos de la cultura, se convierte en el lugar a partir del cual ser testigo de la lucha entre dos literacies, dos regímenes de conocimiento, abre nuevas avenidas para tratar 
de responder a las preguntas surgidas por la proliferación de los medios mecánicos y numéricos. El espacio de la intermedialidad es el espacio híbrido donde el discurso se abre a lo visible y la visualidad se convierte en discursiva en un movimiento que perturba la construcción lingüística y filosófica que las tenía separadas. La intermedialidad es diferente a la intertextualidad o la interalteridad, ya que ella implica la centralidad de la técnica en la comprensión de dinámicas diferentes. Al concentrarse en el medium, la intermedialidad no puede ignorar la superficie sobre la que la letra toma forma, ni la base material del medium, las modalidades de transmisión, la materialidad de la comunicación; no puede tolerar la abstracción, ni las oposiciones binarias. La intermedialidad, que no separa el orden de los símbolos del orden de las cosas, es una teoría y una práctica de la diferencia. Es la calidad del milieu en el que vivimos.

\section{El milieu intermedial}

El material de todo arte: el ladrillo, el color, la arcilla, el cuerpo, la voz, el son y, finalmente, la vida, la "realidad bruta o fantasmática" (Pasolini, Le cinéma de poésie, 137), es, existe en relación a un medium: ya se trate de la pintura, del lenguaje, de la arquitectura, de la escultura, del teatro, de la danza, de la cámara fotográfica o cinematográfica, del video, la relación es, en efecto, primaria en la mediación. Preguntémonos por la naturaleza y los lugares de la mediación. ${ }^{10}$ ¿Qué entendemos por mediación? ¿La mediación comparte la naturaleza dinámica y efímera del acontecimiento? ¿Acaso remite a un sujeto que, gracias a un medio/media, o aún más, a una técnica, representa, transforma, comunica una realidad? ¿Se sitúa al interior de la

${ }^{10} \mathrm{He}$ desarrollado esta reflexión en mi libro El cine y el fin del arte. Teoría y práctica cinematográfica en Lev Kuleshov, en particular en el tercer capítulo, 36-46. 
filosofía de la representación y de la economía de la verdad o nos muestra más bien los límites? ¿A qué concepto de técnica/ tecnología remite el concepto de mediación?

La mediación es el hacer de un medium. El término medium es un préstamo del latín, "centro"; en particular tomo del Dictionnaire historique de la langue francaise la definición de medium en tanto que "sustancia, milieu en el que tiene lugar un fenómeno". Esta definición (siglo xvI) une lo material, la materia misma - la sustancia, el espacio - y lo que hace acontecimiento - el movimiento, el subvenir de un fenómeno- . Los dos son inseparables. El medium es entonces ya un milieu y un hacer, una acción o una serie de acciones. Para explicar la naturaleza compleja y dinámica de la mediación tomo de Heidegger la figura del puente en su ensayo "Construir, habitar, pensar" (170-193).

El puente se tiende "ligero y fuerte" por encima de la corriente. No junta sólo dos orillas ya existentes. Es pasando por el puente como aparecen las orillas en tanto que orillas. El puente es propiamente lo que deja que una yazga frente a la otra. Es por el puente por el que el otro lado se opone al primero. Las orillas tampoco discurren a lo largo de la corriente como franjas fronterizas indiferentes de la tierra firme. El puente, con las orillas, lleva a la corriente las dos extensiones de paisaje que se encuentran detrás de estas orillas. Lleva la corriente, las orillas y la tierra a una vecindad recíproca. El puente coliga la tierra como paisaje en torno a la corriente [...] El lugar no está presente ya antes del puente. Es cierto que antes de que esté puesto el puente, a lo largo de la corriente hay muchos sitios que pueden ser ocupados por algo. De entre ellos uno se da como un lugar, y esto ocurre por el puente. De este modo, pues, no es el puente el que primero viene a estar en un lugar, sino que por el puente mismo, y sólo por él, surge un lugar (183). ${ }^{11}$.

${ }^{11}$ Traducción de Eustaquio Barjau, Conferencias y artículos. Texto en línea en Heidegger en Castellano. 
Lo que surge es antes que nada la naturaleza dinámica del puente. Cada pasaje revela (para seguir con Heidegger) su función de conectar, de religar, de crear, de metamorfosear los espacios en lugares. El puente transforma el mundo en el que se inscribe. El puente es del orden del reencuentro, del devenir, del acontecimiento, de la metamorfosis. Es una acción —el pasaje del puente, el puente en tanto que pasaje - que produce, a la vez, las orillas y la región que acoge al puente y a la corriente sobre el que se extiende. La técnica audiovisual es como un puente, arrojada entre nuestros sentidos (sobre todo, evidentemente la vista y el oído) y el mundo, sobre la corriente de la experiencia (sensorial, cognitiva y afectiva). La acción de atravesarlo es casi infinita porque casi infinito es el número de "usuarios" con sus "tácticas" y sus "ruses/argucias" (Certeau, L'invention du quotidien, XXXIII-LIII). Como el puente que transforma los lugares alrededor de la corriente en orillas y conecta la corriente con las orillas y el país, la técnica audiovisual hace de la vida un material cinematográfico o televisivo y une nuestra experiencia, el mundo y las diferentes mediaciones en una mutua vecindad. Lo que importa es lo que se produce alrededor del puente, el devenir de la región, el devenir cine de la vida, el reencuentro del cine y la vida, el reencuentro de la mediación cinematográfica con otras mediaciones de la experiencia, hasta el infinito. Ese "lugar que no existe antes del puente" es la metáfora más elocuente, me parece, del milieu intermedial que es a la vez una técnica, lo que pone en relación los "usos" que hacemos de él, el espaciotiempo en el que se inscribe, la memoria de otras técnicas y de otros lugares (el puente contiene otros puentes recorridos, fotografiados, filmados, pintados, dibujados). Un medium contiene siempre otros, el milieu es necesariamente intermedial.

Esta reflexión demasiado rápida nos conduce a la pregunta sobre la técnica planteada más arriba: ¿a qué concepto de técnica nos remite ese puente, ese medium? Él no es sólo el instrumento, el medio para llevar a cabo una causa: por ejemplo, 
la de atravesar la corriente; podemos entenderlo como medio y reconducirlo a una causa, pero eso sería reductor. Al preguntar al sujeto de la técnica, como él lo dice, Heidegger se remonta al concepto de téchnê que, asociado al de epistémê, designa un modo de conocimiento. El conocimiento ofrece aperturas y, en esa medida, es del orden del develamiento (alêtheúein). La téchnê es, entonces, un modo del alêtheúein.

Devela de lo oculto algo que no se produce a sí mismo y todavía no se halla ahí delante, y por ello puede aparecer y acaecer de este modo o de este otro [...]. Este hacer salir de lo oculto coliga de antemano el aspecto y la materia de barco y de casa y los reúne en la cosa terminada y vista de un modo acabado, determinando desde ahí el modo de la fabricación. Lo decisivo de la téchnê pues, no está en absoluto en el hacer y el manejar, ni está en la utilización de medios, sino en el hacer salir de lo oculto del que hemos hablado. En tanto que éste, pero no como fabricación, la téchnê es una pro-ducción traer-ahí-delante (Heidegger, "La pregunta por la técnica", 19. Traducción modificada). ${ }^{12}$

La pro-ducción de la que se trata aquí es la que se distingue de la producción de un objeto a partir de una representación abstracta. La téchnê no separa la idea de la materia; idea y materia están, más bien, separadas en la fabricación de un objeto a partir de su imagen, que lo trasciende y lo precede. Tal cabeza esculpida, por ejemplo, nace de eso que la técnica puede conocer de una persona en el barro y el rostro se percibe siempre por el escultor a través de su téchnê: su mirada sobre la gente que encuentra (en el metro, en la calle, en el mercado), sabe que la arcilla podrá captar y acoger el acontecimiento de sus cuerpos. La técnica audiovisual, ¿no sería el develamiento de la vida en tanto que imagen y sonido, duración, anacronismo, ritmo, más

${ }^{12}$ Traducción de Eustaquio Barjau, Conferencias y artículos. Texto en línea en Heidegger en Castellano. 
que el medio para transmitir un mensaje o contar una historia? (Y eso no quiere decir que no existan mensajes o historias relatadas, como tampoco que el barco no sirva para ir sobre el agua y la casa para habitarla). Regresemos, entonces, a las preguntas del inicio: la mediación ¿remite, remite a un sujeto que, gracias a un medio/ medium, o más aún, a una técnica, representa, transforma, comunica una realidad? ¿Se sitúa al interior de la filosofía de la representación y de la economía de la verdad o muestra más bien sus límites?

¿Qué sucedería si retomáramos el relato del puente en otra perspectiva: la de un sujeto (individual o colectivo) que, después de haber estudiado la región y las necesidades de la población, construyera el puente con el espíritu de fomentar el progreso y los intercambios? Eso sería el "gran relato" de la conquista de la naturaleza, del sujeto soberano y de la evolución social. La técnica sería ahí percibida como el medio, el instrumento que el hombre se ha dado para transformar el milieu. La dinámica inherente al otro relato: la diferencia de las orillas y de los múltiples pasajes, el devenir de la región, la relación entre la técnica, la experiencia, el milieu y el hacer humano no serían ya pertinentes ni visibles. Los límites de este "gran relato" comienzan a aparecer gracias al trabajo de los medias, en particular de la fotografía, el cine y la radio que hacen al sujeto reemerger hacia la "realidad física", ${ }^{13}$ embrollando los límites entre real e imaginario así como los límites entre lo material y lo ideal, y se dan a pensar en tanto que formas de mediación más que como instrumentos de las representaciones del mundo. La revelación de la técnica como acontecimiento permite repensar el lenguaje, la escritura, la danza, el teatro, la escultura, la pintura, cualquier otro medio, fuera del "gran relato" moderno de la representación. Pero el puente continúa siendo

${ }^{13}$ Me remito a Siegfried Kracauer, Theory of Film. The Redemption of Physical Reality. 
visto, más a menudo que lo que uno cree, como el medio para atravesar un río, para ir de un lugar a otro, y la cámara cinematográfica como el medio para contar una historia o expresar y suscitar ideas y afectos. Heidegger escribe: "Así, no es el puente el que primero toma un espacio en un lugar para sostenerse, sino que es solamente a partir del puente mismo como nace un lugar." Lo que esta frase nos invita a hacer es pensar en conjunto la técnica, la experiencia, el sujeto y el mundo, pensar la dinámica de la mediación. Por ejemplo, cuando escribimos un ensayo, podemos redactar un plan, establecer un orden en el que vamos a tratar tal o cual otro problema, podemos decidir en qué medida dejaremos que se manifieste nuestra subjetividad, pero es en la escritura donde el problema toma forma, como ella se revela al escritor, que se conecta con otros, es en la escritura donde mi subjetividad dialoga y se hibrida con otras. Los pensamientos y los afectos que creía poder expresar continúan formándose en el acto de escribir. El puente-escritura no se tiende entonces, entre dos pensamientos/afectos-lugares ya reconocibles y definidos; es la escritura, cargada de la memoria de otros pensamientos y afectos y de otras formas de escribir, lo que hace nacer y desarrollarse a esos pensamientos y esos afectos singulares. En Le père sauvage, escenario de un film jamás realizado, Pasolini pone en escena a un profesor blanco y progresista que enseña en una escuela colonial de una ciudad africana. Pide a sus alumnos elaborar una composición sobre su ciudad. Pero la lengua de la escuela no es el medium de su experiencia vivida, ni de la transmisión de esta experiencia; es el medium donde los alumnos piensan y experimentan el mundo virtual conocido en las obras de Occidente. "Sus pobres ojos estupefactos, Davidson está sentado sobre su cama en el dormitorio común [...] Tiene su cuaderno sobre las rodillas. Y quiere escribir. Pero él no sabe qué escribir, porque no sabe cuáles son sus sentimientos sobre su ciudad en la cultura que se lo demanda" (Pasolini, Il padre salvaggio, 13. Trad. mía). 
La lengua no es el vehículo de toda experiencia, la lengua de una cultura, su posibilidad de decir y sus maneras de decirlo, pero aún más importante, los sentimientos y los pensamientos cobran vida en un medium que no preexiste a él. Ahí se reencuentra la dinámica del puente que hace nacer el lugar. Davidson encontrará su manera singular de construir y atravesar el puente entre las culturas, sumergiéndose en la realidad física de su país y escribiéndola sin representarla.

Él va a sentarse allá cerca del bosque, bajo el monumento lúgubre de un árbol de caoba. Trata aún de dar vida a sentimientos que sabe que tiene [...]. Davidson ha escrito su pueblo, su madre, sus hermanos, los ritos, las supersticiones, las danzas [...] la caza de las fauces [...] el león [...] El profesor lo escucha, encantado, palabra por palabra, IMAGEN POR IMAGEN (14. Trad. mía).

En la búsqueda de una escritura que pudiera hacer encontrarse al África y al Occidente, Davidson crea un movimiento que une su experiencia, el mundo y las diferentes mediaciones en una mutua cercanía. La téchnê de su escritura pro-duce sus sentimientos en relación a su vivencia entre dos culturas. No sólo el acontecimiento de la palabra en Davidson está doblada por el acontecimiento de la imagen en el escenario - -El profesor lo escucha, encantado, palabra por palabra, IMAGEN POR IMAGEN"- que remite al film imaginario sin no obstante detenerse ahí. La intermedialidad reúne el texto y el film en un mismo soplo y los límites entre los dos resultan vagos.

Me gustaría concluir esta excursión en los meandros de la intermedialidad con otra imagen pictórica, que esta vez parece configurar la dinámica de la mediación y el devenir del milieu intermedial. En el cuadro de Mark Tansey, White on White, los Beduinos y los Inuits se encuentran con sus perros, sus camellos, sus trineos y sus tiendas de campaña en un milieu blanco donde la arena del desierto se confunde con la nieve del gran Norte, un viento crea un movimiento que reúne a los dos grupos en un todo donde sólo 
las diferencias son visibles. Las diferencias y no las oposiciones. El viento borra las oposiciones mezclando la nieve y la arena, el frío y el calor, las acciones de los Inuits y la de los Beduinos. Sugiero pensar en la intermedialidad como ese viento que nos hace cambiar de tabla de operación privándonos de objetos definidos e invitándonos a pensar la relación en la materia.

\section{REFERENCIAS}

Certeau, Michel de, L'invention du quotidien. L'Arts de faire, París, Gallimard, 1990.

Cisneros, James, "Remains to be seen. Intermediality, Ékphrasis and Institution", en Intermédialité et socialité. Histoire et géographie d'un concept, Marion Froger y Mûller Jûrgen (dir.), Mûnster, Nodus Publikationen, 2007.

_ - "Imaginary of the End, End of the Imaginary. Bazin and Malraux on the Limits of Painting and Photography", en Cinémas, vol. 13, 3, Printemps, 2003, 149-169.

EISENSTEIN, Elizabeth L., La révolution de l'imprimé dans l'Europe des premiers temps modernes, París, La Découverte, 1991.

Deleuze, Gilles y Felix Guattari, Qu'est-ce que la philosophie?, París, Les Éditions de Minuit, 1991.

Derrida, Jacques, L'Université sans condition, París, Galilée, 2001. Gaudeault, André Marion Philippe, "Un média naît toujours deux fois [...]”, en Sociétés et Répresentations. La Croisée des médias, París, CREDHESS, 9, 2000.

Godzich, Wlad, The Culture of Literacy, Cambridge, Harvard University Press, 1994.

- The Language Market under the Hegemony of the Image, Valence, Eutopías, Working Papers, vol. 29, 1993.

HeIDEGGer, Martin, "L'époque des 'conceptions du monde'", en Chemins qui ne mènent nulle part, París, Gallimard, 1962, 253-322.

__, "Bâtir, habiter, penser", en Essais et conférences, París, Gallimard, 1958 ["Die Frage nach dem Technik" [1953], "La pregunta por la técnica" y "Bauen, Wohnen, Denken" [1951], "Construir, 
Habitar, Pensar", en Conferencias y artículos, trad. Eustaquio Barjau, Barcelona, Ediciones del Serbal, 1994, 9-37 y 127-142]. Kracauer, Siegfried, Theory of Film. The Redemption of Physical Reality, Princeton, Pricenton University Press, 1997.

LyotaRd, Jean-François, La condition postmoderne, París, Les Éditions de Minuit, 1979.

Man, PAul DE, "The Resistance to Theory", en The Resistance to Theory, Minneapolis, The University of Minnesota Press, 1986. Mariniello, Silvestra, El Film: el Fin del Arte, Madrid, Cátedra, 1992. - El cine y el fin del arte. Teoría y práctica cinematográfica en Lev Kuleshov, Madrid, Cátedra, 1992.

_- "Commencements", en Intermédialités, Naître, Printemps, 2003.

Méchoulam, Eric, Entrevista "Éclaircies à travers les brumes de l'intermédialité. Entretien avec Éric Méchoulan ( $1^{\text {re }}$ partie)", en Spirale, 229, noviembre-diciembre 2009.

Michelson, Annette (ed.), Kino-Eye. The Writings of Dziga Vertov, trad. Anna Giordano y Poncio Almodovar, Berkeley/Los Ángeles/Londres, University of California Press, 1984.

Pasolini, P. P., "Le cinéma de poésie", en L'expérience hérétique, París, Payot, 1976.

—_ Il padre salvaggio, trad. Silvestra Mariniello, Turín, Einaudi, 1975.

Readings, Bill, The University in Ruins, Cambridge, Massachusetts/ Londres, Harvard University Press, 1996.

Weber, Samuel, "Television, Set and Screen", en Mass mediauras, Stanford, Stanford University Press, 1996, 108-128. 